\title{
Inconsistency Among Beliefs, Knowledge, and Teaching Practice in Mathematical Problem Solving: A Case Study of a Primary Teacher
}

\author{
Tatag Yuli Eko Siswono, Ahmad Wachidul Kohar, Ika Kurniasari, \& Sugi Hartono \\ Faculty of Mathematics and Natural Science, Surabaya State University \\ tatagsiswono@unesa.ac.id \\ bangwachid@gmail.com \\ ika.kurniasari@gmail.com \\ sugihartonounesa@gmail.com
}

\begin{abstract}
This is a case study investigating a primary teacher's beliefs, knowledge, and teaching practice in mathematical problem solving. Data was collected through interview of one primary teacher regarding his beliefs on the nature of mathematics, mathematics teaching, and mathematics learning as well as knowledge about content and pedagogy of problem solving. His teaching practice was also observed which focused on the way he helped his students solve several different mathematics problems in class based on Polya's problem solving process: understand the problem, devising a plan, carrying out the plan, and looking back. Findings of this study point out that while the teacher's beliefs, which are closely related to his problem solving view, are consistent with his knowledge of problem solving, there is a gap between such beliefs and knowledge around his teaching practice. The gap appeared primarily around the directive teaching which corresponds to instrumental view he held in most of Polya's process during his teaching practice, which is not consistent with beliefs and knowledge he professed during the interview. Some possible causes related to several associate factors such as immediate classroom situation and teaching practice experience are discussed to explain such inconsistency. The results of this study are encouraging, however, further studies still need to be conducted.
\end{abstract}

Keywords: inconsistency, problem solving, teacher beliefs, teacher knowledge, teaching practice

\section{Introduction}

Developing problem solving skills in mathematics classroom is an important task for teacher. However, there is an evidence that many teachers have not met requirements to implement a problem solving approach in their classroom (Hollingsworth, Lokan, \& McCrae, 2003). Also, some considerations have been given by many scholars regarding teachers' quality of implementing problem solving (Ernest, 1989; Fennema, Carpenter, \& Peterson, 1989; Raymond, 1997). Such factors include teacher beliefs, teacher knowledge, and teachers teaching practice. Bray's (2011) study results suggest that teachers' beliefs seem the most likely influence on how teachers structure class discussion whereas teachers' knowledge appear to drive the quality of teachers' responses within classroom discussion.

In an attempt to look for the relationship between teachers' teaching practice and teachers' beliefs, some tried to conceptualize and develop models of such relationship (see Anderson et al., 2005; Fennema et al., 1989; Raymond, 1997) while others reported how such models were confirmed by practical interest (see Purnomo, Suryadi, \& Darwis, 2016; Siswono, Kohar, Kurniasari, \& Astuti, 2016; Siswono, Kohar \& Hartono, 2017). For instance, conceptually, Fennema and her colleagues emphasize that classroom instruction is determined 
by teachers' decisions, which in turn are influenced by the interaction between knowledge and beliefs. Regarding mathematical problem solving, specifically such interactions were then studied by Siswono et al. (2017) with three secondary mathematics teachers and found that teachers' beliefs have a strong relationship with teachers' knowledge about problem solving. In particular, the instrumental teachers' beliefs in their study were consistent with insufficient knowledge about problem solving, while both platonist and problem solving teachers' beliefs were consistent with sufficient knowledge of either content or pedagogy of problem solving. Thus, the study showed consistency between teachers' beliefs and knowledge. Does such a relationship work for primary teachers? How consistent is teachers' teaching practice with mathematical problem solving? Hence, this study aims to examine the relationship among the beliefs, knowledge, and teaching practice regarding mathematical problem solving of a primary teacher.

\section{Theoretical Background}

\section{Beliefs About Mathematical Problem Solving}

Beliefs can be defined as one's knowledge, theories and conceptions and include whatever one considers as true knowledge, although he or she cannot provide convincing evidence (Pehkonen \& Pietilä, 2003). It is noted that beliefs in mathematical problem solving are closely related with beliefs about the nature of mathematics as well as teaching and learning mathematics. Viholainen, Asikainen, and Hirvonen (2014) explained that beliefs about the nature of mathematics influence beliefs concerning mathematical problem solving and vice versa, and that beliefs concerning the learning of mathematics also imply beliefs about the teaching of mathematics. Meanwhile, earlier Ernest (1989) stated that teachers' view on the nature of mathematics affected the role of the teacher in classroom teaching and learning. He presented three different philosophical views of the nature of mathematics: instrumental, platonist, and problem solving. In attempt to simplify these views, Beswick (2005) summarized connections among the nature of mathematics, mathematics learning, and mathematics teaching (see Table 1).

Table 1.

Summary of Beliefs About the Nature of Mathematics, Mathematics Teaching, and Mathematics Learning

\begin{tabular}{|l|l|l|}
\hline $\begin{array}{l}\text { Beliefs about the } \\
\text { nature of mathematics }\end{array}$ & Beliefs about mathematics teaching & Beliefs about mathematics learning \\
\hline Instrumentalist & $\begin{array}{l}\text { Content focused with an emphasis on } \\
\text { performance }\end{array}$ & $\begin{array}{l}\text { Skill mastery, passive reception of } \\
\text { knowledge }\end{array}$ \\
\hline Platonist & $\begin{array}{l}\text { Content focused with an emphasis on } \\
\text { understanding }\end{array}$ & Active construction of understanding \\
\hline Problem solving & Learner focused & $\begin{array}{l}\text { Autonomous exploration of own } \\
\text { interests }\end{array}$ \\
\hline
\end{tabular}




\section{Knowledge About Mathematical Problem Solving}

Chapman (2015) summarized three types of knowledge for teaching problem solving: problem solving content knowledge, pedagogical problem solving knowledge, and affective factors and beliefs (see Table 2).

Table 2.

Knowledge to Understand Problem Solving

\begin{tabular}{|c|c|c|}
\hline Type of knowledge & Knowledge & Description \\
\hline \multirow{4}{*}{$\begin{array}{l}\text { Problem Solving } \\
\text { Content knowledge }\end{array}$} & $\begin{array}{l}\text { Mathematical problem } \\
\text { solving proficiency }\end{array}$ & $\begin{array}{l}\text { Understanding what is needed for successful } \\
\text { mathematical problem solving }\end{array}$ \\
\hline & Mathematical problems & $\begin{array}{l}\text { Understanding of the nature of meaningful problems; } \\
\text { structure and purpose of different types of problems; } \\
\text { impact of problem characteristics on learners }\end{array}$ \\
\hline & $\begin{array}{l}\text { Mathematical problem } \\
\text { solving }\end{array}$ & $\begin{array}{l}\text { Being proficient in problem solving; understanding of } \\
\text { mathematical problem solving as a way of thinking; } \\
\text { problem solving models and the meaning and use of } \\
\text { heuristics; how to interpreting students' unusual } \\
\text { solutions; and implications of students' different } \\
\text { approaches }\end{array}$ \\
\hline & Problem posing & $\begin{array}{l}\text { Understanding of problem posing before, during, and } \\
\text { after problem solving }\end{array}$ \\
\hline \multirow[t]{2}{*}{$\begin{array}{l}\text { Pedagogical } \\
\text { Problem Solving } \\
\text { Knowledge }\end{array}$} & $\begin{array}{l}\text { Students as mathematical } \\
\text { problem solvers }\end{array}$ & $\begin{array}{l}\text { Understanding what a student knows, can do, and is } \\
\text { disposed to do (e.g., students' difficulties with problem } \\
\text { solving; characteristics of good problem solvers; } \\
\text { students' problem solving thinking) }\end{array}$ \\
\hline & $\begin{array}{l}\text { Instructional practices for } \\
\text { problem solving }\end{array}$ & $\begin{array}{l}\text { Understanding how and what it means to help students to } \\
\text { become better problem solvers }\end{array}$ \\
\hline \multicolumn{2}{|c|}{ Affective Factors and Beliefs } & $\begin{array}{l}\text { Understanding nature and impact of productive and } \\
\text { unproductive affective factors and beliefs on teaching } \\
\text { and learning problem solving }\end{array}$ \\
\hline
\end{tabular}

\section{Teaching Practice on Mathematical Problem Solving}

In understanding teaching practice which regard to problem solving, many scholars have discussed on what best instructional process which teachers require to hold. For example, Franke, Kazemi, and Battey (2007) explained that within the problem solving lesson, teachers need to orchestrate class discussion so that students share multiple problem solving strategies, analyze relations among strategies, and explore contradictions in students' ideas to provide greater insight into the mathematical focus. Additionally, the four Polya's stages of solving a problem, i.e. understanding the problem, making a plan, carrying out the plan, looking back, also imply how to teach problem solving (Ontario Ministry of Education, 2008). However, it is noted that those phases should be used flexibly. For instance, when encountering students who have devised a plan to solve a problem, a teacher should help them realize that while carrying out the plan it may need revision and they may have to try something different. 


\section{Method}

This is a case study which describes qualitatively one Indonesian primary teacher's beliefs, knowledge, and teaching practice regarding problem solving. The teacher was selected from the result of interviewing 10 primary teachers, purposively chosen from Surabaya city using a set of belief-related tasks discussing the nature of mathematics, mathematics learning, and mathematics teaching. Of all the teachers, we selected XXXX (pseudoname) as our participant since the participant's significant beliefs aligned with the problem solving view he professed during the interview.

Such tasks were arranged in the form of incomplete statements. We provided three options for each incomplete statement illustrating the description of each belief. As an illustration, when asked about what people should learn from mathematics, XXXX was asked to complete the statement by selecting one of the options: (1) to have skills in calculating and applying mathematical formulae or procedures when solving a daily life problem, (2) to be proficient in understanding topics in mathematics, such as algebra; statistics; probability; geometry; and the interrelationships among those topics entirely, and (3) to have thinking skills such as understanding regularities of phenomena, being critical and creative in solving any problems. Then, he explained why he selected his option. Meanwhile, to collect the data about teacher' knowledge, our questions were primarily inspired by Chapman's (2015) category of problem solving knowledge for teaching described in Table 2.

In describing XXXX's teaching practice, we employed several lesson observations of all the three teachers. Due to the need of investigating how teachers helped their students to learn to solve mathematical problems, we provided 10 problems for upper primary school students. An example is provided in Figure 1.

\section{Designing Swimming Pool}

Mr. Tony will design several square-shaped swimming pools. To cover the center of each of swimming pool, he plans to use grey-colored tiles, while to cover the circumference of the swimming pool, he plans to use white-colored tiles. His design is as follows.
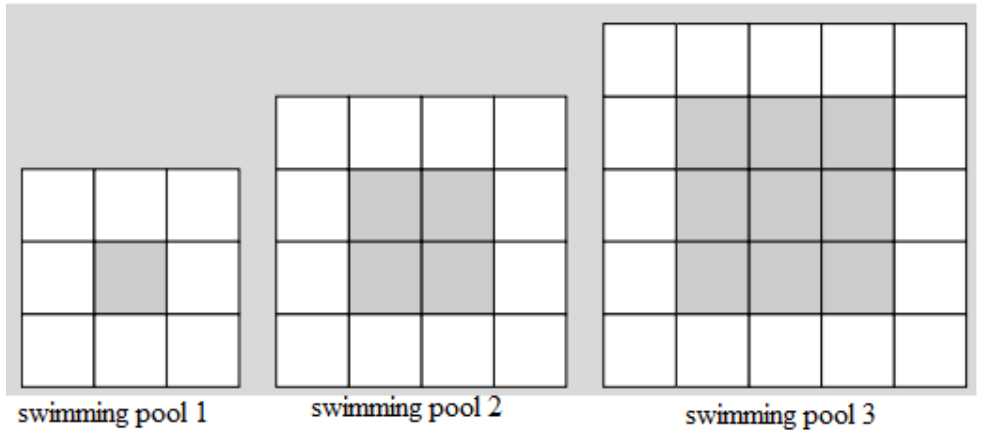

How many grey-colored tiles and white-colored tiles would be in the swimming pool 10? Explain your reasons.

Figure 1. An example of problem used in lesson observation 
To analyze teachers' teaching practice, we were guided by the framework we developed according to Polya's model of solving problem as described in Table 1 . We focused on the significant feature of how each teacher guided students in each problem solving stage. The feature was then categorized as to whether it reflected directive teaching, the teaching where the teacher explains a concept, gives an example of applying the concept, and finally offers the students some exercises for practicing problems (Antonius et al., 2007), or consultative teaching where teacher emphasizes guiding students to actively and independently construct new knowledge by using their prior knowledge and experiences (Blum \& Ferri, 2009). Table 3 summarizes list of questions for the observation data of teacher's teaching practice.

Table 3.

Framework for Describing Teachers' Teaching Practice

\begin{tabular}{|c|c|}
\hline Problem Solving Stages & Questions \\
\hline \multirow{4}{*}{$\begin{array}{l}\text { Teacher guides students } \\
\text { to figure out the problem } \\
\text { by thinking and } \\
\text { expressing their opinions } \\
\text { on the problem posed. } \\
\text { (Understand the problem) }\end{array}$} & How does the teacher engage students in understanding the problem situation? \\
\hline & $\begin{array}{l}\text { How does the teacher encourage students to understand the problem by } \\
\text { associating the problem with their prior knowledge? }\end{array}$ \\
\hline & How does the teacher make sure students understand the problem? \\
\hline & $\begin{array}{l}\text { How does the teacher ask the students to identify the required information for } \\
\text { the purpose of solving the problem? }\end{array}$ \\
\hline \multirow{5}{*}{$\begin{array}{l}\text { Teacher guides students } \\
\text { to select a/an appropriate } \\
\text { strategies/model of } \\
\text { finding solution and draw } \\
\text { attention that it is very } \\
\text { likely to change during } \\
\text { the process of solving the } \\
\text { problem. (Devising a } \\
\text { plan) }\end{array}$} & $\begin{array}{l}\text { How does the teacher guide students to discover the relationship between the } \\
\text { information that has been presented with information that does not exist but had } \\
\text { been identified in the previous step in preparing the plan for settlement? }\end{array}$ \\
\hline & $\begin{array}{l}\text { How does the teacher give students opportunity to determine their own strategy } \\
\text { that is used, rather than directing students on a particular strategy? }\end{array}$ \\
\hline & $\begin{array}{l}\text { How does the teacher give students opportunity to convey the idea of a strategy } \\
\text { that was selected by the students/groups? }\end{array}$ \\
\hline & $\begin{array}{l}\text { How does the teacher provide reinforcement or provide guidance to improve the } \\
\text { model/ strategies that have been determined? }\end{array}$ \\
\hline & $\begin{array}{l}\text { How does the teacher make sure that every student/group has determined the } \\
\text { strategy/plan of each? }\end{array}$ \\
\hline \multirow{2}{*}{$\begin{array}{l}\text { Teacher guides students } \\
\text { to implement what is } \\
\text { planned. } \\
\text { (Carrying out the plan) }\end{array}$} & $\begin{array}{l}\text { How does the teacher guide students to implement the determined } \\
\text { strategy/plan? }\end{array}$ \\
\hline & $\begin{array}{l}\text { How does the teacher ensure every student/group has arrived at a solution, } \\
\text { regardless whether it is correct, partially correct, or incorrect? }\end{array}$ \\
\hline \multirow{8}{*}{$\begin{array}{l}\text { Teacher guides students } \\
\text { to evaluate the process } \\
\text { and the solution resulted } \\
\text { in the previous process. } \\
\text { (Looking back) }\end{array}$} & $\begin{array}{l}\text { How does the teacher ask the students to look back on the process and the } \\
\text { solution they found? }\end{array}$ \\
\hline & $\begin{array}{l}\text { How does the teacher ask students to identify the strengths and weaknesses of } \\
\text { the solution they found? }\end{array}$ \\
\hline & $\begin{array}{l}\text { How does the teacher ask difficulties experienced by students during solving the } \\
\text { problem? }\end{array}$ \\
\hline & $\begin{array}{l}\text { How does the teacher give students opportunity to present their } \\
\text { solution/strategies to other students? }\end{array}$ \\
\hline & $\begin{array}{l}\text { How does the teacher ask students to rethink other strategies/solutions may be } \\
\text { more likely effective/better to answer the problem? }\end{array}$ \\
\hline & $\begin{array}{l}\text { How does the teacher guide students to consider the various solutions } \\
\text { discussed? }\end{array}$ \\
\hline & $\begin{array}{l}\text { How does the teacher guide students to make generalizations of the processes } \\
\text { and solutions obtained in a more general/complex problem? }\end{array}$ \\
\hline & $\begin{array}{l}\text { How does the teacher guide students to identify possible changes of solutions if } \\
\text { the situation/context of the initial problem is changed? }\end{array}$ \\
\hline
\end{tabular}




\begin{tabular}{|l|l|}
\hline Problem Solving Stages & Questions \\
\hline & $\begin{array}{l}\text { How does the teacher guide students to draw out conclusions based on the } \\
\text { discussion with the emphasis on the main ideas as a reflection for the further } \\
\text { problem solving experience? }\end{array}$ \\
\hline
\end{tabular}

Analysis of data was carried out by firstly reducing data, displaying data, and finally drawing conclusions and verification (Miles \& Huberman, 1994). The conclusions were sought to understand the characteristics of beliefs and knowledge espoused by the teacher and how these two variables interact with each other in shaping his teaching practice on problem solving.

\section{Results}

\section{XXXX's Beliefs}

In most instances examined on the nature of mathematics, XXXX had a problem solving view, except when he expressed his ideas about the success of the completing strategy he made when solving mathematics problem. He said,

I believe that the completion strategy I planned will always be managed to find a solution to the problem, as long as the concepts and mathematical procedures I have used are correct, because in mathematics, it has actually been in accordance with the agreement.

He also agreed that mathematics is about thinking and capturing real world phenomena. He argued,

...by studying mathematics correctly, we will be critical in using various types of problems existing in this world.

XXXX's beliefs in teaching mathematics are also in line with his view on problem solving. XXXX showed a consistent view in placing the students as the focus of learning in teaching practice. He said,

I think our students have a great potential so that we need not to act as if they were unable to learn. Rather, we simply provoke their potential so that they can flourish, hence, the teacher's role is as facilitator in learning mathematics.

He said that to clarify the errors made by the students within a learning activity, he agreed to give students an opportunity to discuss the ideas that emerged from their thinking and to determine which one is best to clarify their misunderstandings. According to him,

Sometimes students can be more creative when giving reasons why his/her other job is right or wrong, for example when there are children who miscalculate in front of the class, there are also some children who give their opinions about how the calculation should be done.

However, in motivating students to learn mathematics, he also concurred with the platonist view. 
I agree that reward will only be effective when students are actively working to achieve the goal of learning I set, this is important for them in order to grow their own personal motivation.

In addition, in relation to learning resources that students should access, he said,

They need some resources of learning mathematics, not only from school books, designed by teacher, but also designed by themselves, the benefit is they will be more active and more appreciated.

Regarding how students should learn mathematics, XXXX's views were also consistent with the type of problem solving beliefs as well. When asked to complete the statement about the best way to learn strategies to solve mathematical problems, he said,

In order students are able to solve problems, students should strive to solve problems by their own way based on their knowledge and experience.

In addition, $\mathrm{XXXX}$ also advised his students to learn all the strategies available because he thought,

This [learning problem solving strategies] is important for them, because although it could not be used on a particular problem, however, it will be likely used in other type of similar or even unfamiliar problems.

In looking at the use of calculators, XXXX suggested,

I will give them opportunity to use a calculator for problems demanding reasoning, not for question that only assess how to calculate.

\section{XXXX's Knowledge}

Regarding XXXX's knowledge, he stated that a mathematics question is called a problem or not depending on whether a student is able to solve it and whether the question indicates something challenging and interesting. He also knew that sometime students do not have total knowledge about a problem. According to him,

How could problem of the equation of a straight line like being presented in this question becomes problem for elementary school students? They do not have enough experience about it...

He also expressed his understanding on the types of problem, and when interviewed and asked to give examples of open problems, he proposed,

...determine as many as possible possibilities of size of a rectangle that has an area of 40 $\mathrm{cm}^{2}$.

XXXX's pedagogical knowledge seemed sufficient to explain how to implement problem solving instruction in class. He said,

I usually ask students to read the question and ask them to understand the intent of the problem, and provide direction during discussion about what is being asked and what is known. Then, in groups or pairs, I ask them to discuss and find the idea of strategies. After that, I ask them to work on appropriate strategies. Well, if there are students who 
need some helps, I will come to guide them. At the end of the lesson, some groups will present their solution to clarify whether there were making mistakes as well as paying particular attention to the answers from other friends.

\section{XXXX’s Teaching Practice}

Table 4 presents the summary of XXXX's teaching practice while guiding his students to solve six different problems.

Table 4.

Summary of XXXX's Teaching Practice on Problem Solving Stages

\begin{tabular}{|c|c|c|c|c|c|c|}
\hline \multirow{2}{*}{$\begin{array}{l}\text { Problem } \\
\text { solving } \\
\text { stages }\end{array}$} & \multicolumn{6}{|l|}{ Problems } \\
\hline & Food Boxes & $\begin{array}{l}\text { Designing } \\
\text { Swimming } \\
\text { Pool }\end{array}$ & $\begin{array}{l}\text { Guessing } \\
\text { Friend's Age }\end{array}$ & Book Pages & $\begin{array}{l}\text { Daily Rice } \\
\text { Supply }\end{array}$ & Travelling \\
\hline $\begin{array}{l}\text { Understanding } \\
\text { problem }\end{array}$ & Consultative & Consultative & Directive & Consultative & Directive & Directive \\
\hline $\begin{array}{l}\text { Devising a } \\
\text { plan for } \\
\text { strategies }\end{array}$ & Directive & Directive & Directive & Directive & Directive & Directive \\
\hline $\begin{array}{l}\text { Carrying out } \\
\text { the plan }\end{array}$ & Consultative & Consultative & Consultative & Consultative & Consultative & Directive \\
\hline Looking back & Directive & Directive & Consultative & Consultative & Consultative & Directive \\
\hline
\end{tabular}

Table 4 shows that the most significant feature describing XXXX's teaching practice can be seen from the second stage of his guidance, which is directive teaching on devising a plan for strategies. For example, he offered to calculate the number of boxes in every layer using the area of rectangle formula in 'Food Boxes' problem.

XXXX: Let me see your work...how to obtain this result [pointing].

Student: We calculated the number of boxes in the first layer, which is 45 from 9x5

XXXX: Don't you see that there are some missing boxes in this part?

Student: Oh yes. I see there are two missing boxes here

XXXX: So, what should you do next?

Student: I must remove two boxes, so that the remaining are 43 boxes.

In 'Book Pages' problem he suggested students to think of the possibilities of page numbers so that the sum of two first page numbers and two last page numbers must be 98 , and told students to use this knowledge of dividing integers by fractions on the problem.

Another description of his typical teaching practice appeared in his guidance when students clarified their solution in the looking back activities. With most problems, XXXX seemed to not engage students to actively clarify their answers. Rather, he showed the correct answers of the problem and just asked which group got the answer, asking those who got 
incorrect ones to revise as shown in the following talk on 'Designing of Swimming Pool' problem.

XXXX: How can you analyze the pattern of the design?

Student: (no response)

XXXX: Let's make a table representing the number of tiles for grey-colored tile, and white-colored tile [drawing a table]. Now I put that the number of grey tiles in pattern 1 is 1 , while the number of white tiles is 8 . In pattern 2 , there are 4 grey tiles and 12 white tiles. What's next?

Students: 16 white tiles...20 tiles...

XXXX: How about the grey tiles? Can you see the pattern?

Students: (no response)

XXXX: This is called square number pattern. So, it starts from 1, 4, 9, and so on.

Continue this pattern.

He ended the process of solving the problem with the following instruction.

XXXX: [while drawing pattern of tiles on whiteboard] Let's count the number of tiles as we predicted.

Students: one, two, three... twenty five, twenty six...

XXXX: Now, we can conclude that our prediction is correct.

The practice above indicates XXXX's used directive teaching when checking whether the number of grey tiles and white tiles they predicted fitted with the actual number of tiles represented in the model of tiles arrangement instead of letting his students present their own way of checking the reasonableness of the solution they found.

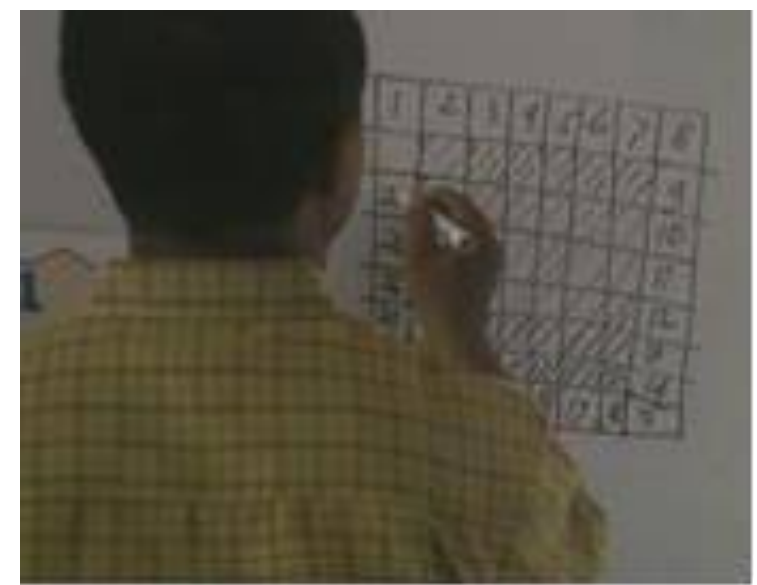

Figure 1. XXXX's demonstration on checking the problem solutions

XXXX mostly performed directive teaching for several activities. XXXX also used consultative teaching for several other activities. For example, XXXX tried to check the mathematical procedures his students performed by either visiting every group to ensure the correctness of the procedure or asking students to write their calculation on the whiteboard.

We also found that among the four stages, the process of guiding students to work on mathematical procedures in carrying out the plan seemed most aligned with the consultative form of teaching and not the other three stages. 


\section{Discussion}

Our findings indicate that the problem solving view held by XXXX seemed consistent with his knowledge about problem solving. Nevertheless, we found an inconsistency between his beliefs and knowledge toward his teaching practice. XXXX agreed that students should be actively engaged in finding strategies and discussing ideas emerging from their thinking and determine to clarify their misunderstandings. Regarding knowledge, he also professed that in problem solving instruction, a teacher should ask students to present their solution to clarify their answers from other friends' opinion. However, when it came to his teaching practice, he seemed to perform differently from his espoused beliefs and knowledge in most stages of Polya's four processes, particularly while guiding students to devise a plan and look back.

In most cases, he did not let students to think of the appropriate strategies. Rather, he offered such strategies to the class although he then asked them to do in groups. He also seemed to confirm the solution found by the students by telling the correct solution instead of asking them to verify other possible procedures and answers, or even extend the problem into a more complex problem.

Concerning on this finding, the researchers discussed this kind of inconsistency. Empson and Junk (2004) asserted that even if teachers profess certain beliefs which are aligned with mathematical teaching reform, such as problem solving view, it does not mean that they will surely perform in ways consistent with those beliefs. Anderson, White, and Sullivan (2005) added that the inconsistency between beliefs and teaching practice may be results of many influences, some of which are social context and teachers' level of thought. Meanwhile, Raymond (1997) added that such inconsistency can be resulted from teachers' social norms and immediate classroom they encounter. In this study, we found that immediate classroom is particularly about the mathematics at hand, students' abilities, and time constraint as the main causes of this inconsistency. As an evidence, after the lessons ended, we interviewed XXXX to ask him about how often he offered problem solving tasks like he had just used in his class. He said,

I often give problems to my students, however, the problems are not as challenging and complex as the problems I just gave to them ... because several problems seemed very difficult to them, I aimed the big idea on how to solve. In my experience, they will likely find difficulties to determine what formula or what procedure if the problems are given in words.

Thus, it indicates his worry about his students' lack of ability and the complexity of the problems at hand as well as his teaching experiences. 
Further explaining inconsistencies, Raymond (1997), argued that it arises not only because of the immediate classroom and teaching experience but also the cumulative effect of other influences on teaching practice, such as time constraints, social teaching norms, past school experience, and teacher education program. However, we did not study these factors intentionally.

To conclude, we would highlight that while the teacher's beliefs, which were closely related to problem solving view, were consistent with his satisfactory knowledge of problem solving, there was an inconsistency between such beliefs and knowledge with his teaching practice. The gap appeared primarily on the use of directive teaching which is aligned to an instrumental view that he held in most of Polya's process during his teaching practice, primarily when guiding students to devise a plan for determining appropriate strategies, which was not consistent with beliefs and knowledge.

\section{Acknowledgment}

We would like to thank the Ministry of Research and Higher Education for the research grant in the second year of 2016. Our deep appreciation also goes to the Rector of Surabaya State University, and the Dean of the Faculty of Mathematics and Natural Science, Surabaya State University, and Prof. Allan L. White from the University Western Sydney, Australia.

\section{References}

Anderson, J., White, P., \& Sullivan, P. (2005). Using a schematic model to represent influences on, and relationships between, teachers' problem-solving beliefs and practices. Mathematics Education Research Journal, 17(2), 9-38. https://doi.org/10.1007/BF03217414

Antonius, S., Haines, C., Jensen, T. H., Niss, M., \& Burkhardt, H. (2007). Classroom activities and the teacher. In W. Blum, P. L. Galbraith, H.-W. Henn, \& M. Niss (Eds.), Modelling and applications in mathematics education (pp. 295-308). New York: Springer.

Beswick, K. (2005). The belief/practice connection in broadly defined contexts. Mathematics Education Research Journal, 17(2), 39-68.

Blum, W., \& Ferri, R. B. (2009). Mathematical modeling: can it be taught and learned? Journal of Mathematical Modelling and Application, 1(1), 45-58.

Bray, W. S. (2011). A collective case study of the influence of teachers' beliefs and knowledge on error-handling practices during class discussion of mathematics. Journal for Research in Mathematics Education, 42(1), 2-38. 
Chapman, O. (2015). Mathematics teachers' knowledge for teaching problem solving. LUMAT, 3, 19-36

Empson, S. B., \& Junk, D. L. (2004). Teachers' knowledge of children's mathematics after implementing a student-centered curriculum. Journal of Mathematics Teacher Education, 7, 121-144

Ernest, P. (1989). The impact of beliefs on the teaching of mathematics. In P. Ernest (Eds.), Mathematics teaching: The state of the art (pp. 249-253). New York: Falmer.

Fennema, E., Carpenter, T. P., \& Peterson, P. (1989). Teachers' decision making and cognitively guided instruction: A new paradigm for curriculum development. In N. F. Ellerton, \& M. A. Clements (Eds.), School mathematics: The challenge to change (pp. 174-187). Geelong: Deakin University Press.

ranke, M. L., Kazemi, E., \& Battey, D. (2007). Mathematics teaching and classroom practice. In F.K. Lester Jr. (Eds.), Second handbook of research on mathematics teaching and learning (pp. 225-256). Charlotte, NC: Information Age.

FHollingsworth, H., Lokan, J., \& McCrae, B. (2003). Teaching mathematics in Australia: Results from the TIMSS 1999 video study. Melbourne: Australian Council of Educational Research.

Miles \& Huberman (1994). Qualitative data analysis: An exposed sourcebook ( $2^{\text {nd }}$ Ed.). London: SAGE Publication Ltd.

Ontario Ministry of Education. (2008). A guide to effective instruction in mathematics, kindergarten to grade 6 - Volume two. Toronto: Author.

Pehkonen, E., \& Pietilä, A. (2003). On relationships between beliefs and knowledge in mathematics education. Proceedings of the CERME-3 (Bellaria) ..., 1-8. Retrieved from http://www.cimm.ucr.ac.cr/ciaemIngles/articulos/universitario/concepciones/On Relationships Between Beliefs and Knowledge in Mathematics Education.*Pehkonen, Erkki; Pietil?, Anu. *Pehkonen, E. Relationships between Beliefs ... 2003.pdf

Purnomo, Y. W., Suryadi, D., \& Darwis, S. (2016). Examining pre-service elementary school teacher beliefs and instructional practices in mathematics class. International Electronic Journal of Elementary Education, 8(4), 629-642.

Raymond, A. M. (1997). Inconsistency between a beginning elementary school teacher's mathematics beliefs and teaching practice. Journal for Research in Mathematics Education, 28(5), 550-76.

Siswono, T.Y.E., Kohar, A. W., Kurniasari, I., \& Astuti, Y. P. (2016). An investigation of secondary teachers' understanding and belief on mathematical problem solving. Journal of Physics: Conference Series, 693(1), p. 012015. IOP Publishing. https://doi.org/10.1088/1742-6596/693/1/012015

Siswono, T.Y.E, Kohar, A.W., \& Hartono, S. (2017). Secondary teachers' mathematicsrelated beliefs and knowledge about mathematical problem solving. Journal of Physics: Conference series, 812(1), p. 012046. IOP Publishing. 
https://doi.org/10.1088/1742-6596/812/1/012046

Viholainen, A., Asikainen, M., \& Hirvonen, P. E. (2014). Mathematics student teachers' epistemological beliefs about the nature of mathematics and the goals of mathematics teaching and learning in the beginning of their studies. Eurasia Journal of Mathematics, Science and Technology Education, 10(2), 159-171. https://doi.org/10.12973/eurasia.2014.1028a 

Southeast Asian Mathematics Education Journal 2017, Vol. 7 No. 2 